\title{
Judith Weir's Instrumental Music as Description
}

\author{
A Música instrumental descritiva de Judith Weir
}

\author{
Kheng K. Koay \\ National Sun Yat-Sen University, Kaohsiung, Taiwan \\ kkhengk@yahoo.com
}

\begin{abstract}
This study explores Judith Weir's abstract descriptive technique in her instrumental music, Distance and Enchantment (1988) for piano quartet and Musicians Wrestle Everywhere for ten instruments (1994). Folksongs and a location used and described in the music, respectively, are interpreted and "produced" through musical characters and mood. In most cases musical characters and gestures have a tendency to associate musical motion to arouse images. The decisions, ideas and styles in these compositions may be applied to works in other genres and her later works, as well.
\end{abstract}

Keywords: Judith Weir's music; 20th-century music; music as description.

Resumo: Este artigo discute técnicas descritivas abstratas da compositora inglesa Judith Weir em duas composições instrumentais: Distance and Enchantment [Distância e encantamento] para quartet com piano, de 1988, e Musicians Wrestle Everywhere [Músicos lutam em todo lugar], para dez instrumentos, de 1994. Canções folclóricas e locais mencionados e descritos na música, respectivamente, são interpretados e "emulados" por meio de caráter e atmosferas. Na maioria dos casos, o caráter musical e os gestos apresentam uma tendência de associar movimentos com a sugestão de imagens. As decisões, ideias e estilos adotados nestas composições podem server de modelo na interpretação de obras em outros gêneros, inclusive de sua produção tardia.

Palavras-chave: música de Judith Weir; música do século XX; música descritiva.

Data de recebimento: 03/12/2015.

Data de aprovação final: 18/03/2016. 


\section{1 - Introduction}

Folk songs, folklore, things, events and landscapes have been major inspirational sources for composers over many centuries, and often have been incorporated into or represented in their music. In the late 20th-century composers generated different compositional techniques to address the mood of stories, events and locations in their compositions. Some also engaged in various practices and experimentations of composing abstract musical descriptions based on these resources.

It is undeniable that Judith Weir possesses a creative musical imagination in setting up and capturing such moods of stories, poems, folksongs, folklore and environments that have inspired her. Musical ideas and elements that draw from these sources and other extramusical inspirations are often found and reproduced in her music, including instrumental compositions. Evocative titles are also given to evoke images. "She was very interested in unusual texts and poems...," says Holloway. "She has a very special feeling for words and atmosphere and mood" (TILDEN, 2014).

Thus this study explores Weir's abstract descriptive technique in her instrumental music, focusing on her Distance and Enchantment (1988) and Musicians Wrestle Everywhere (1994). The two works are quite diverse in their use of techniques and ideas; each work has its own role in Weir's development in compositional technique. This essay examines how two folksongs and a location, respectively, are interpreted and "produced" through musical characters and mood. What techniques are used to set the atmosphere and to provide images in these compositions? How does Weir keep the musical culture of the folksongs she quotes? These two compositions certainly illustrate Weir's experiment with various strategies of mood description in her music. The decisions, ideas and styles in these compositions may be applied to works in other genres and her later works, as well. Thus, the paper provides an understanding of her individuality as a composer, providing greater familiarity with her descriptive techniques in her instrumental music. 
KOAY, Kheng K. (2016) Judith Weir's Instrumental Music as Description. Per Musi. Ed. by Fausto Borém, Eduardo Rosse and Débora Borburema. Belo Horizonte: UFMG, n.33, p.59-78.

Indeed, Weir has explored possibilities in musical language that render a rich variety of imagery descriptions in the two compositions. One musical character follows another; the music has a tendency to associate musical motion to arouse images, and this is especially true in Musicians Wrestle Everywhere. Aspects of musical organization such as tempo, rhythmic characters, dynamics and texture, and the selection of instruments have played a major role in the compositions to evoke images and set the mood. Distinct musical characters, musical gestures and materials are also carefully selected to portray events and atmosphere of the folksongs and to connote possible images of location. In addition, some musical associations are employed in combination so that each reinforces the other; it is particularly obvious in her Distance and Enchantment.

As is her custom, Weir quotes folk songs and poems, developing them in her own music interpretation. Weir once said that, "from a fairly early time I was experimenting with folk influences" (HUGHES and WEIR, 2005, p.21). Each musical style and presentation in her music differs from one work to another. Her works walk through the mood of the "stories" told in the folk songs and "description" of a location differently, and that makes them pleasurable and interesting to hear.

While language, texts, songs and film or theater music have an ability to "imitate" images aided by visual or narrative elements, instrumental music denotes very little of the perceivable objects or phenomena. It is certainly an interesting challenge for Weir as a composer, since her instrumental music constitutes an abstract essence of the environment.

By the 1980s, Weir had written a long catalogue of vocal works that were inspired by stories, texts and poems drawn from European, American and Chinese sources in different periods; for example, a 19th-century historical story in King Harald's Saga (1979); an Eastern fantasy in A Night at the Chinese Opera (1986-87); and her Ox Mountain Was Covered by Trees (1990) based on a setting in a text by Mencius, a third century BC commentary on Confucius. There are also works that derive from 11thcentury Taoist texts in her Natural History (1998); Scottish traditional music and 
KOAY, Kheng K. (2016) Judith Weir's Instrumental Music as Description. Per Musi. Ed. by Fausto Borém, Eduardo Rosse and Débora Borburema. Belo Horizonte: UFMG, n.33, p.59-78.

folklore such as in Scotch Minstrelsy (1982); Songs from the Exotic (1987); and A Spanish Liederbooklet (1988), and many others. In addition, her love of the human voice is evident through her so many vocal genres of musical works. All these compositions not only have captured the imagination of Weir with a fresh display of musical characters, but also have demonstrated her natural dramatic gift and a genuine urge to tell stories through music.

Weir's operas and stage works provide a highly structured ordering of experience. Plots and acts are presented with a highly schematized and condensed focus. On the other hand, Weir also attempts to instill her dramatic ideas into her instrumental music; she tries to cultivate referential evocative qualities, and constructs moods and atmosphere that capture the environments that perfectly suit an event or a location by which she has been inspired. Folk songs and poems are often used to evoke their relevance and enhance the mood of the selected story. Indeed, by doing so, her music tells of an environment at a particular time and in a particular place.

Indeed, Weir views music as something similar to "storytelling" and "narrating." She once remarked that "music is created as much in abstract ways as in narrative ways" (BRUCE, 2012). In order to enjoy performing her music, Weir encourages musicians to listen and to find out the story that is told in the work. Vayu Naidu, a storyteller and novelist, commented that Weir "encouraged the musicians to listen to the stories, to inhabit their space, before playing the music she'd written. It wasn't just about coming in on tune" (TILDEN, 2014). Moreover, Weir often provides a short description to her works as a listening guideline. Nevertheless, this approach merely expresses partially the interpretation of her works, particularly her instrumental compositions. A crucial and ultimate element to our understanding of a composition is determining how techniques, musical material and ideas are presented in the composition, finding her uniqueness of describing the work, experiencing the relationship between music and stories; through these a full appreciation can be achieved.

Weir always has a way to "tell", "narrate" and "describe" stories in her compositions. Although the music is abstract, it is nevertheless accessible. The following discussion 
KOAY, Kheng K. (2016) Judith Weir's Instrumental Music as Description. Per Musi. Ed. by Fausto Borém, Eduardo Rosse and Débora Borburema. Belo Horizonte: UFMG, n.33, p.59-78.

will begin with Weir's Distance and Enchantment, followed by the Musicians Wrestle Everywhere.

\section{2- Distance and Enchantment}

In 1988 Weir wrote her Distance and Enchantment for piano quartet, which was dedicated to the Domus Ensemble on their 10th birthday and was premiered by them at the Wigmore Hall, London, on 26th of September, 1989. The composition was inspired by Northern Irish and Scottish folk songs: The Dark Eyed Gipsy (Figure 1) and A ghaoil, lig dhachaihj gu m'mathair mi (My Love, Let Me Home to My Mother) (Figure 2).

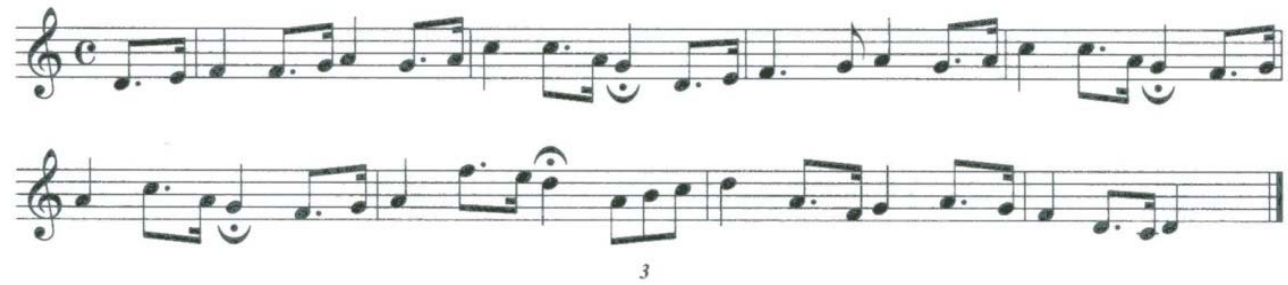

Figure 1 - The Northern Irish folk song The Dark Eyed Gipsy 
A ghaoil, leig dhachaigh gum mhàthair mi

Oh love, let me home to my mother

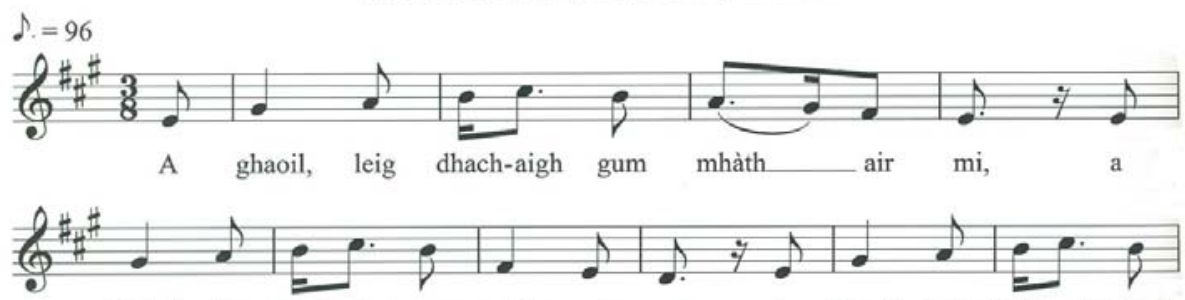

ghràidh, leig dhach-aigh gum mhàth - air mi, a ghaoil, leig dhach-aigh gum
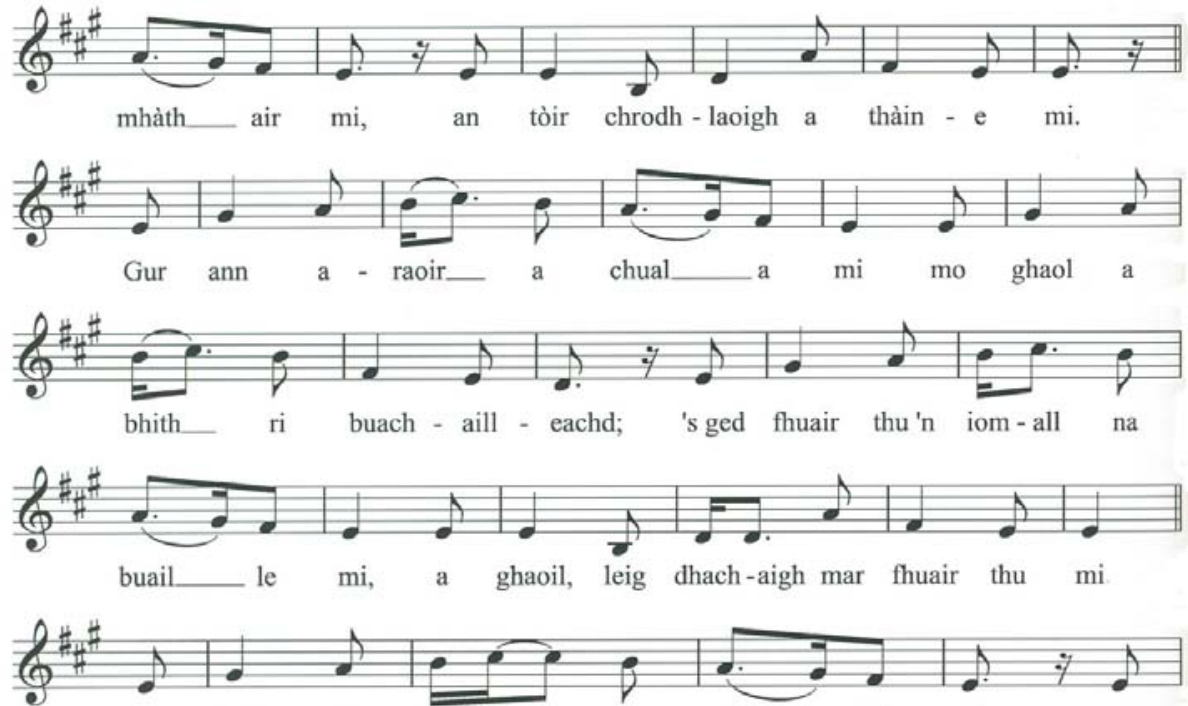

A ghaoil, leig dhach-aigh_ gum mhàth_air mi, a

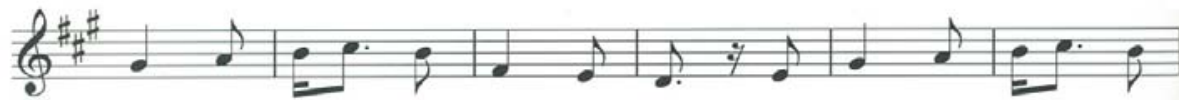

ghràidh, leig dhach-aigh gum mhàth - air mi, a ghaoil, leig dhach-aigh gum

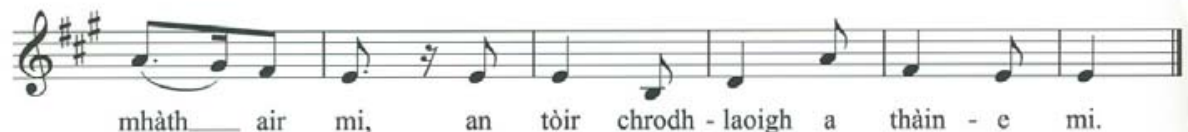

Figure 2 - The Scottish folk song A Ghaoil, lig dhachaihj gu m'mathair mi (My Love, Let Me Home to My Mother)

The former was from Northern Ireland, and the latter from her native country of Scotland. The two folksongs draw on the tragic tales of two women, respectively (WEIR, Chester Music):

The first song, The Dark-Eyed Gypsy, from Northern Ireland, tells of a woman who, of her own volition, leaves her comfortable home to roam the unknown world with a band of gypsies; and the second, A Ghoil, lig dhachaigh gu m'mathair mi from South Unist, Scotland, tells of a girl who wanders a little too far from home on a dark night and is stolen away by the fairies. 
Different musical ideas and sources arising from the two folk themes are used as building material in the composition. Throughout the composition, folk themes are never entirely quoted, instead they are presented in fragmentations. As Lisa Colton claims, Weir's “'foreign' traditions are only lightly hinted at rather than aped. More subtly, folk music or stories from the British Isles are used as the basis for contemporary re-hearings" (COLTON, 2010, p.279).

Indeed, each musical mood and character in the folksong is interpreted differently in Weir's music; expression and musical characters are carefully selected to suit its atmosphere. A full measure break is inserted at measure 125 , dividing the composition into two halves, with the first half on The Dark-Eyed Gipsy and the second half on $A$ Ghoil, lig dhachaigh gu m'mathair mi. Moreover, the musical presentations of each folksong are different and somewhat contrasting in ideas. In the first half of the composition there are constant breaks interrupted by rests in the piano, in contrast to the smooth musical flow of the strings. This handling is somewhat reversed in the second half; the smooth musical flow occurs in the piano and viola. The violin and cello are constantly interrupted by rests as the music progresses.

Weir's general musical settings are sensitive to the mood of the two folksongs' texts. To capture the mysterious atmosphere of the disappearance of people the music is generally written in an intense mood. The first half begins with somewhat similar rhythmic patterns, short note-values in small groups of two to four recurring pitches within an octave range in fast tempo in the piano. It is accompanied by strings in both repeated and long sustaining notes (Figure 3). The intensity of the musical flow in the piano is further stressed by the interruption of rests, creating fragmentation. 

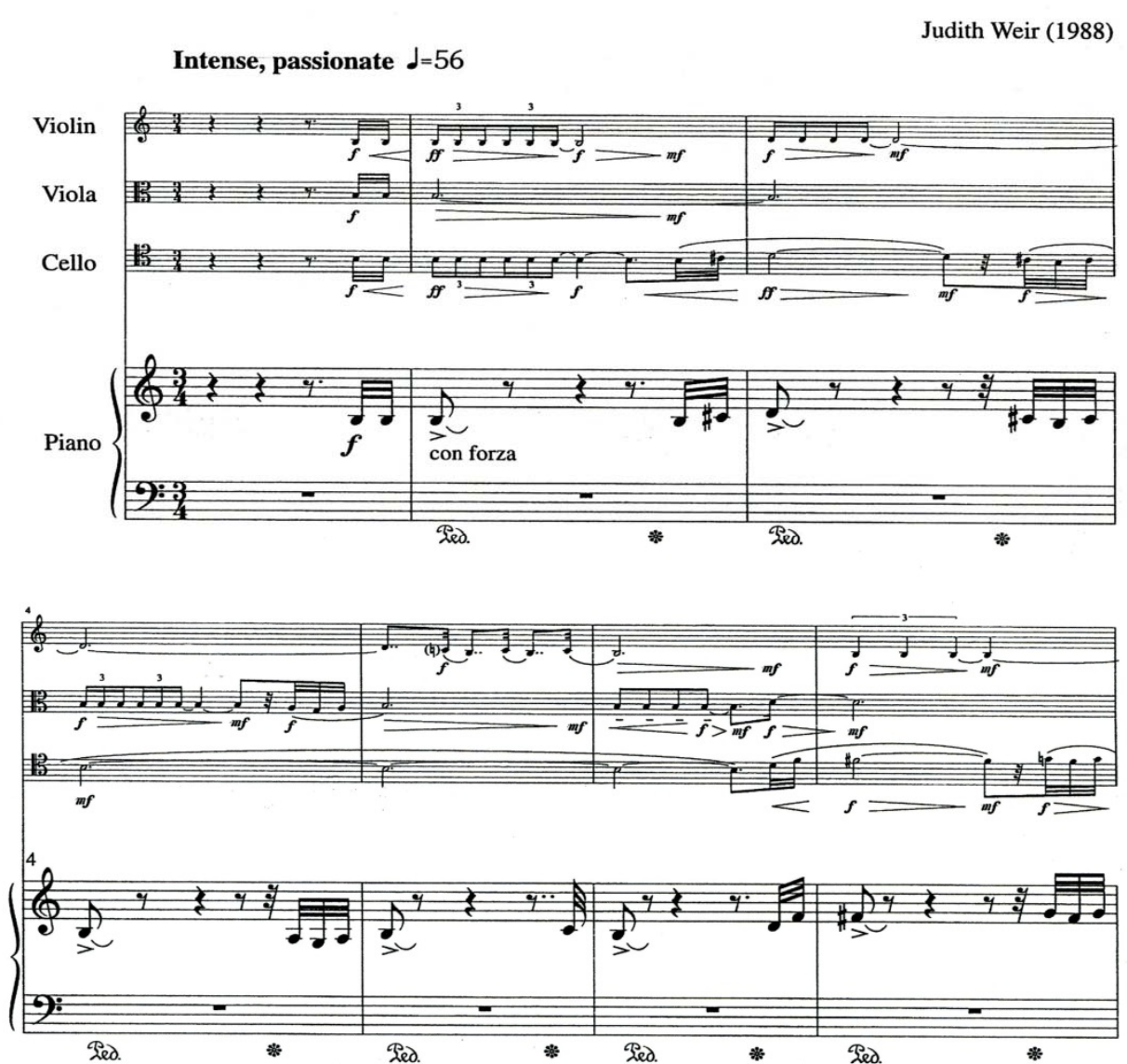

Figure 3 - An intense mood at the opening of Distance and Enchantment

The second half begins with busy, fast repeating quintuplet and triplet rhythmic group patterns, with a slight noticeable change of pitches that is introduced in the piano accompaniment.

To some extent, the music is written in such a way that it is similar to writing a song; it tends to have a main melodic line supported by an accompaniment. This is particularly obvious in the second half of the music, where there is a long, lyrical, melodic flow in the viola, with an accompaniment in other parts and piano that occasionally double the melodic line. This type of song-like writing style can also be seen in her other instrumental pieces such as Arise! Arise! You Slumbering Sleepers (1999) for piano, violin, viola and cello, and the second movement of her Piano Quartet (2000). The former is based on an English/American folksong called of the same name, and the latter is based on a French folk song called "Blanche comme la neige." Weir's use of a 
KOAY, Kheng K. (2016) Judith Weir's Instrumental Music as Description. Per Musi. Ed. by Fausto Borém, Eduardo Rosse and Débora Borburema. Belo Horizonte: UFMG, n.33, p.59-78.

song-writing style in these compositions has its musical rationale, mainly for the compositions' intimate relationship to folk songs.

At a surface level, the fragmentation and recurring pitches in the piano at the opening of the first half may create a sense of wonder and uncertainty. A closer study reveals that the pitches B3-C\#4-D4 (with reference to middle $\mathrm{C}=\mathrm{C} 4$ ) at measures 2-3 and D4F4-F\#4 at measures 6-7, taken together, form the opening of the pitch contour of the folk song, The Dark-Eyed Gypsy. Indeed, it is a way by which Weir introduces a folk melody: hinted, rather than giving it away. This also occurs in the second half of the composition. A fragment of the folk melody, A Ghoil, lig dhachaigh gu m'mathair mi, does not occur until measure 259 , with a slight difference in pitch contour from the original folk song.

In the music, there is more than a matter of the arrangement of pitches. Certain musical characters in the composition also show to have significant meanings, as well. For instance, Weir ends the first half of the music by gradually fading the dynamic levels away and easing the tension, symbolizing the forever disappearance of the woman that tells in the folksong.

According to tradition, the folksong A Ghoil, lig dhachaigh gu m'mathair mi (My Love, Let Me Home to My Mother) is a girl singing to a water-horse, which is a dangerous supernatural inhabitant of the sea or loch; it often transforms into different forms such as a beautiful horse, a pony or a human to seduce pretty young maidens (GILLIES, 2010, p.431). The "sea" image and the flow of the water is interpreted through the use of fastrunning thirty-two-note quintuplets in arpeggio-like in the piano in the second half. In the past, fast, continuous running notes in repeated pattern have been used in many compositions with subjects that are related to the flowing of a river or brook; suffice to mention the musical gesture found in "Wohin?" in Schubert's song cycle Die schöne Müllerin and "Scene by the Brook" in Beethoven's Pastoral Symphony.

Despite the fact that there are no clear definitive markers that indicate the "fairies" moment in the second half of the music, there is, however, beginning at measure 226, 
an unexpected joyous, sharp contrast in dynamics and dance-like moment in all instrumental parts, with heavy shifting of accents and emphasis on weak-beats which might suggest the seducing activities of "fairies." This moment certainly creates a dramatic tension that catches the attention of the listeners, and seemingly interprets an event that has happened in the "story."

In addition, although there is no straightforward representation such as words and lyrics in her instrumental pieces, Weir often brings back musical materials from her song collections as a way as to provide a clue, establishing clearer images and interpretations in the music. For example, in the first half of the composition, beginning at measure 94 in the piano accompaniment, the arpeggio-like musical gestures in contrary motion recall a similar musical gesture that was introduced in the piano accompanied part in The Gypsy Laddie in her early song collection Scotch Minstrelsy (1982). Thus, it is not difficult for one to identify and associate such a musical gesture as a gypsy character. Similarly, the four-note (C4-E4-F\#-G) (Figure 4) pitch contour at the end of the second half is also quoted from her vocal work, The Song of the Girl Ravished Away by the Fairies in the South Ubist, from an early song collection, Songs from the Exotic (1987). Indeed, the fragments of songs can function as references for her instrumental music. 

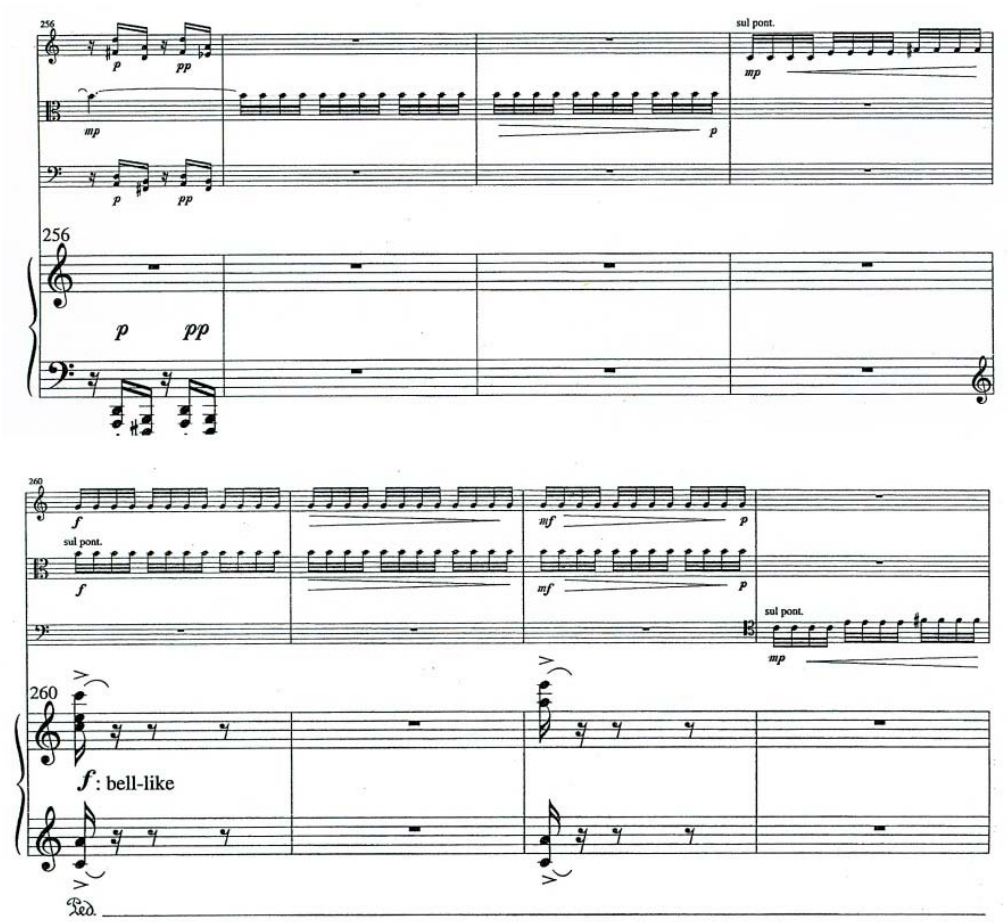

Figure 4 - The four note (C4-E4-F\#-G) pitch contour beginning at measure 259 in the Distance and Enchantment

Interestingly, not only are musical ideas and styles derived from her previous works, but they are also re-employed and reintroduced in her later works such as the second movement of her I Broke Off a Golden Branch (1991) for piano, violin, viola, cello and bass, and towards the end of the second movement of her Piano Quartet (2000) for piano violin, viola and cello. Similarly, some musical materials from her String Quartet (1990) are recalled from her early songs on the medieval Spanish romances and ballads from Banffshire, Scotland. Weir views her own source from her early music as, to some extent, a model for her new compositions; one work can also be seen as a source and stylistic reference for her later works.

In keeping with the Irish and Scottish musical traditions in the first half of her piece, an up-beat is well suited to begin the opening of the composition and a change of musical characters; an example can be seen at measure 54. Indeed, like in many Irish folk tunes, as Travis claims, "the broad outlines of rhythm, such as beat patterns, are quite simple in Irish music. Tunes of all types open almost invariably on the up-beat" (TRAVIS, 1938, 
p.464). In fact, not only is an up-beat employed by Weir, but she also composes the sound that captures the music traditions of Ireland and Scotland, since folk music was often related to national cultures and sounds. Although she does not employ traditional instruments such as a bagpipe, a sustaining sound like a drone is used in the music. Anne Lorne Gillis once wrote that "three musical instruments are directly associated with Gaelic tradition: Clàrsach (or small Celtic harp), fiddle, and the bagpipes," and the links between "Gaelic singing [folksongs] and the bagpipes are, quite simply, inextricable" (GILLIES, 2010, p.xxiv, xxv). An example in the composition is at the opening of the music where all the string instruments take turn in keeping a sustaining note on B3 with un-noticeable added pitches, creating a drone effect.

Because the music is associated with folk songs, traditional scales and modes are used to reinforce the musical content. An example can be found at the opening two phrases (measures 1-9) of the section where the music seems to provide a sense of B minor with a raised fourth (or Aeolian with a raised fourth). Another example is between measures 23-28 where the music seems to progress through the B melodic minor scale. Nevertheless, in general, the ambiguity in harmonic function is certainly evident. In other words, the music is tonal but not based on harmonic principles. Nevertheless, Weir's music is still very comprehensible, even though she does not use any existing melodies or texts.

A different way in which Weir deploys musical description and continues to exercise a creative imagination in her instrumental music is evidenced in her Musicians Wrestle Everywhere (1994). Daily routines, events and ideas are triggered by sound and transformed into images, allowing each individual listener to make his or her own visual image and emotional association.

The composition was commissioned under the "Sound Investment" scheme. It is a onemovement work for ten players and is scored for flute, oboe, clarinet, bass clarinet, horn, trombone, percussion, piano, cello and bass. The work was written for the Birmingham Contemporary Music Group, and was first performed by that Group, under the direction of Andrew Parrott, in Birmingham in 1995. 
The title of this composition comes from a poem Wrestle Everywhere by Emily Dickinson, which was completed in 1924. The poem describes ambient sounds such as singing birds, brass bands and church hymns surrounding the poet at her beloved Amherst. What is interesting in this piece is that she has tried a different approach in ideas; she conceives images of her own surrounding, revealing the environment and complicated living style of her community. These images are described not through words, but music. It is a challenge to Weir both in compositional writing and imaginative power. Indeed, in instrumental music composers can only illustrate a succession of moods and atmospheres; how the listener discovers the meaning depends on how well the ideas and materials are exploited and presented in the music.

Today, living in a modern world, one experiences various sounds surrounding us, including noise. In addition to sounds of singing birds and church hymns as presented in the poem, Weir hears noises of the waking town; people passing-by and crossing the road talking in all sorts of languages; the daily noise of traffic; shops opening; a mixture of sounds in the street markets-all the sounds to which she is sensitively attuned in a busy day. She said (WEIR, program note),

Although much of my previous work has been based on exotic folk-song traditions of the world, I have often wondered if I could write down the street music of my own urban environment. To this end, I started taking note of sounds that caught my ear as I walked around at home. At first I undertook this exercise in a satirical spirit, thinking of the pastoral tradition in music, from Vivaldi's Four Seasons to Maxwell Davies. Where they heard trilling birds, trilling brooks and fragrant showers of rain, I heard wind turbulence from a nearby traffic intersection, Nigerian pop music out of a tower block, and wind chimes in the back garden of a crumbling squat.

Probably nothing recognizable of such inspirations can be heard in the muchdeveloped musical language of Musicians Wrestle Everywhere, but I feel personally affectionate towards this material which originates, however distantly, in the exotic landscapes of London SE17. While writing the piece, I discovered Emily Dickinson's poem, which seems to suggest, in the very modern 
KOAY, Kheng K. (2016) Judith Weir's Instrumental Music as Description. Per Musi. Ed. by Fausto Borém, Eduardo Rosse and Débora Borburema. Belo Horizonte: UFMG, n.33, p.59-78.

way of Cage and Feldman, that music is all around us if we only care to listen to

it.

\section{3 - Musicians Wrestle Everywhere}

With a desire to depict her surrounding environment, Weir reflects the sounds of the streets of London in Musicians Wrestle Everywhere for flute, oboe, clarinet, bass clarinet, horn, trombone, percussion, piano, cello and bass. Different musical styles, ideas and characters are employed to project the modern and cosmopolitan city. Indeed, in the music, a particular musical gesture and pattern give us some possible ideas and images of what Weir intends to describe. The compositional techniques used in the composition certainly contribute much to the modern point of view. To some extent, tone painting, texture and instrumental articulations are skillfully utilized to provide a richer sense of images of where she lives.

Her musical descriptions in the composition are set from one moment to another by stylistic changes and measure breaks. There is an immediate sense of a beginning, musically. The repeated rhythmic pattern in pizzicato is somewhat fast-paced, and indicates a way of starting Weir's musical description in the composition, giving rise to an image of the beginning of a busy day (Figure 5). This opening fast figuration also creates an illusion of speed that is reminiscent of fast-pace walking. Such a musical method brings to mind Schubert's Heidenröslein and many other works with "walking" musical gestures. Indeed, Weir once claimed that "Schubert's world is a place where I can find constant inspiration and strength" (WEIR, Piano Trio).

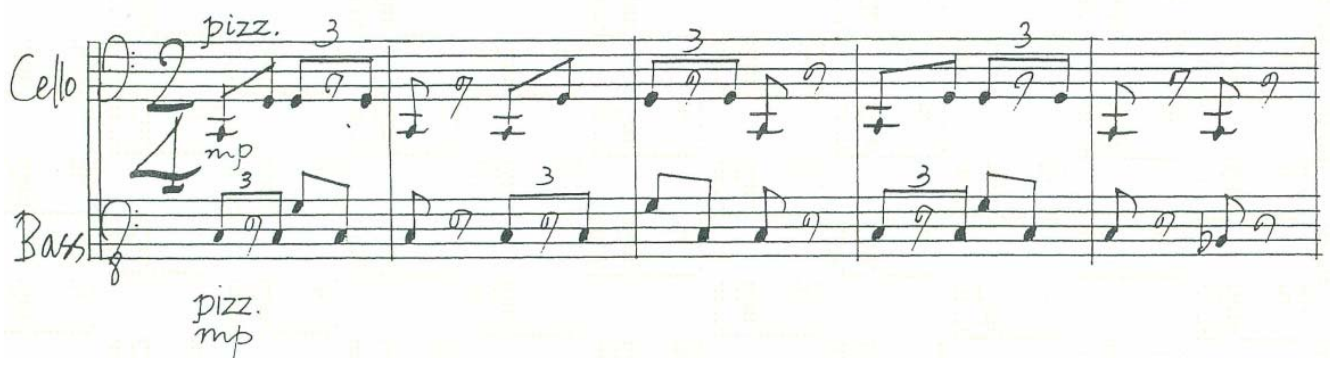

Figure 5 - An image of the beginning of a busy day with fast walking-pace at the opening of Musicians Wrestle Everywhere 
In fact, throughout the music different musical gestures in repeated patterns may suggest walking bass-like styles. Examples can be seen beginning at measures 123,131, 207 and 236; each of the "walking" ideas vary from others in musical characters, tempo and articulations. Moreover, what Weir introduces here is distinctly different from the Baroque musical fashions found in Arcangelo Corelli's Trio Sonatas. Irregular rhythmic patterns and off-beat stresses are emphasized in her composition, giving rhythmic energy that has a lively and jazzy manner. There are times when musical events are constructed entirely from walking bass-like patterns; for example, the opening passage of the piece and the musical event that occurs at the beginning at measure 207 (Figure $6)$.
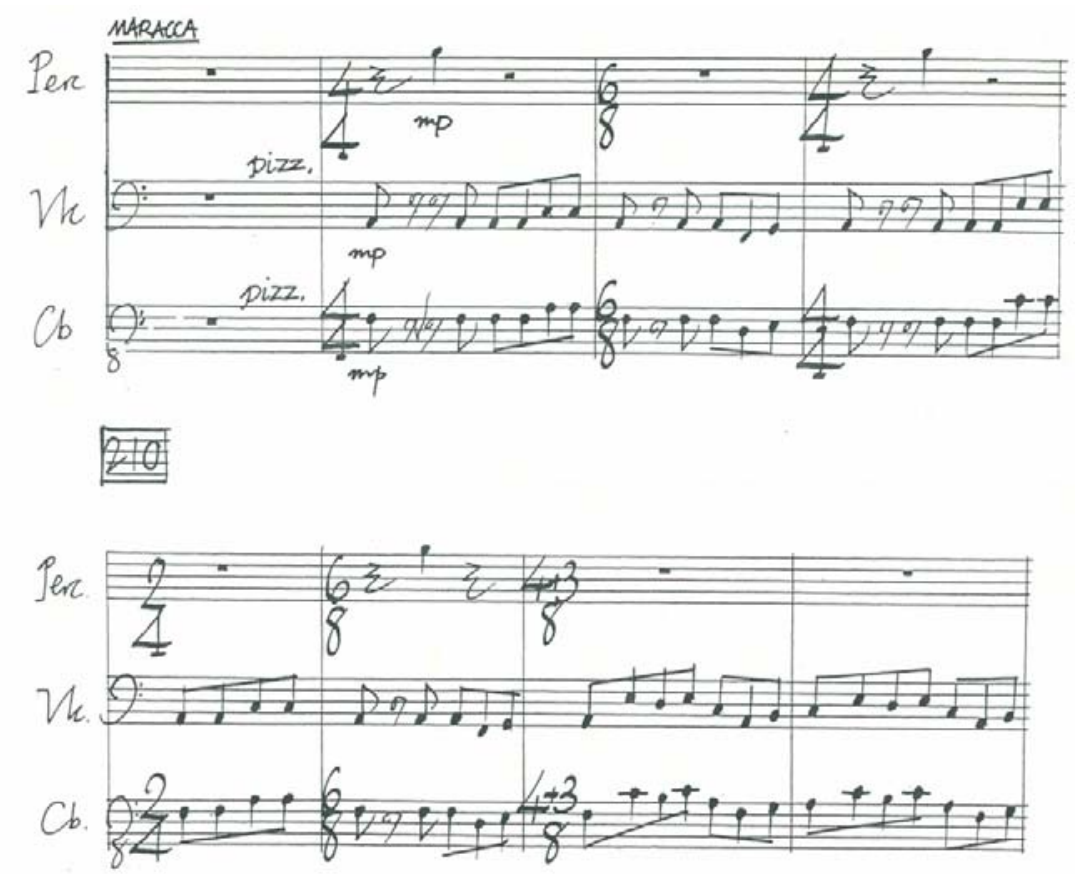

Figure 6 - Walking bass-like patterns beginning at measure 207 in Musicians Wrestle Everywhere

In addition, the opening walking-bass in arch or mordent-like musical contour (C-G-C) functions as a basic idea and as building material for the music, connecting the entire composition. For example, an opening of a lyrical melody that begins at measure 69 in horn and a new musical character that begins at measure 207 are written in this musical contour. 
KOAY, Kheng K. (2016) Judith Weir's Instrumental Music as Description. Per Musi. Ed. by Fausto Borém, Eduardo Rosse and Débora Borburema. Belo Horizonte: UFMG, n.33, p.59-78.

Because what Weir depicts is the environment of a modern and cosmopolitan city, and in order to interpret the sounds of her neighborhood, she embraces popular idiomsfor example, the Nigerian pop music emanating from a tower block. Groups of pitches are either presented in leaps, or are often separated by rests in a vigorous manner. Recurring triplet figures are heavily employed, especially at the opening of the composition. Rhythmic energy is created though pop-like off-beat, irregular accented markings, syncopation and lively rhythms. This musical fashion is also formed, in part, by the environment in which she grew up. Weir encountered pop musical culture at a young age. "When I was growing up, the first new music that I heard was in the 1960s and, as we know, there was quite a doctrinaire modern music scene then. I still like a lot of music from the 50s and 60s and enjoy the rare occasions to hear major works from that period," she said (BRUCE, 2012).

Weir is a great observant composer who has made many significant sounds in music that evokes images. For instance, she uses percussion instruments such as metal coil, glockenspiel and crotales to create wind-chime sounding. There are times when Weir clearly imitates the sound of chimes blown by the wind. A pitch or a group of pitches in irregular rhythmic patterns with different note-values and tempo are employed, creating images of the chimes blown by a breeze, or by a strong wind. An example is the gentle swinging chime sound presented at the beginning of measure 99; each pitch that is separated by rests is presented between metal coil and crotales. This light and gentle swinging sound is heard as if the chime is moved by a breeze.

Indeed, Weir's pictorial writings are drawn on for different musical ideas. Every description made and arranged tends to render some possible images. Instruments are carefully selected to produce a particular soundscape. Maraca, for example, is used to simulate the sound of nature that can be comparable to a cicada sound. It occurs at the beginning of measure 207, along with the walking bass-like gesture. This musical event may give rise to an image of a park, garden, or places full of trees, which are often evoked and associated with listeners' daily experience. Weir's love for nature is evident; she "bikes around London and is a keen walker and very proud of her 
KOAY, Kheng K. (2016) Judith Weir's Instrumental Music as Description. Per Musi. Ed. by Fausto Borém, Eduardo Rosse and Débora Borburema. Belo Horizonte: UFMG, n.33, p.59-78.

allotment," and she and Vayu Naidu "frequently walk their pets together in south London parks" (TILDEN, 2014).

Maracas are one of the most recognizable percussion instruments that are popularly used in Latin America and Caribbean musical cultures. They are often employed in the rhythm section of Latin American dance bands and can also be found in Western pop bands. Weir may be using this unique sound colour of the instrument to bring to mind the diverse ethnic culture in the city.

Indeed, our surroundings are differentiated by various rates of motion and tempo occurring simultaneously, such as the motion of fast/slow in our daily living. This is also illustrated in the music. Beginning at measure 69 , while other instruments are lively and agile in musical characters, a lyrical melodic line in long-note values and tienotes is introduced in horn, showing apparent contrast between the horn and other instruments. There are also times when simultaneously each instrument is given a different musical activity, replete with a dynamic of life imagery. Indeed, the music is written in such a way that it is as if Weir wants to portray a city environment that is full of activity and everybody has a role in it.

Throughout the composition the flow of music is often interrupted. This is particularly evident beginning at measure 102, where the melodic line in horn is often cut off by the other musical ideas in woodwinds and strings. Although it is impossible to claim outright what Weir had in mind with this musical handling, it does create a sense of responses to distractions one encounters everyday. Indeed, every moment we are lightly distracted by mobile devices, traffic noises, loud music, and other possible sounds and things that surrounded us.

Weir has depicted more than one expected in the music; intriguing ideas are presented. Her conclusion is not a mere ending. Although the dynamic levels decrease, and there is less musical activity and the texture is thin towards the conclusion, the music does not sound as if ending; it concludes on a week-beat in short-note value in the flute as if there is more to come after the measure, symbolizing the continuation of everyday 
KOAY, Kheng K. (2016) Judith Weir's Instrumental Music as Description. Per Musi. Ed. by Fausto Borém, Eduardo Rosse and Débora Borburema. Belo Horizonte: UFMG, n.33, p.59-78.

sounds that never end. Although depicting the sound of a modern city, the music does not sound abstract like in a modernist piece; instead, the musical writing is relatively conventional. Like many of her compositions, although no strict conventional harmonic function is employed, the music here tends to begin and end in $\mathrm{C}$ minor. The pitch $\mathrm{C}$ is also stressed throughout the music. At times the music sounds diatonic. Weir once said (BRUCE, 2012),

\footnotetext{
I was one of the last generation to have big time harmony and counterpoint training... Tonal music for me means a particular system, so what I do isn't like that in my mind and therefore I feel there's not too much danger of my writing derivative tonal music, because I'm not working in that idiom. More often the harmony comes out of a mode or a series.
}

Significantly, Weir prefers to be conservative in musical handling. As with her Distance and Enchantment and many of her other compositions, it is evident that she aims to communicate with her audience.

\section{4- Conclusion}

What I have introduced reveals Weir's creative process. With her passion for setting up moods for stories and images Weir has created some kind of descriptive and stylistic writing that separates her music from other contemporary composers. In these compositions she transforms sentiment into action through musical expression. Each musical characteristic varies from one work to another and even between movements. Musically, it is relatively conventional; tonal and modal language is employed.

In Distance and Enchantment, Weir's thematic borrowings are a less visible part than a deeper dependence on her own sources. Several different musical techniques are involved here. Fragments of the folk themes are employed and given an opportunity for a fresh presentation. The incorporation of existing songs of her own into the composition is used as a way to associate meaning and evoke images. Musical gestures 
KOAY, Kheng K. (2016) Judith Weir's Instrumental Music as Description. Per Musi. Ed. by Fausto Borém, Eduardo Rosse and Débora Borburema. Belo Horizonte: UFMG, n.33, p.59-78.

and dynamics are employed to capture the mood of the folklore. Drone sound, modes and scales are used to reinforce the culture. These techniques are all carefully and aptly tied together, providing not only unique musical contexts and descriptions, but also dramatic tension in Weir's music.

In addition, Weir's ability to restructure folk melodies in fragmenting, paraphrasing them and to recall musical ideas also allow her to exploit similarities in tunes and musical characters which are melodically and textually related in several of her early and later works. Weir intends her sources to be audible, and with these musical references a listener is capable of understanding the piece. On the other hand, without any association with folk songs, Musicians Wrestle Everywhere reaches us through musical imagery description that can be related to our everyday experience. The music represents a unique combination of what she has heard. Percussion instruments are used to produce ambient sounds. Distinct rhythmic activity such as repeating musical patterns that are reminiscent of walking-pace is employed. Rhythmic gestures in an agile and a jazz-based manner may also depict Nigeria pop musical cultures. Indeed, sounds of everyday activity exist in the background of our lives and have been interpreted in the composition.

Simultaneous musical activities in various rates of motion and tempo in different instruments, and distraction and rupture occur to interrupt the flow of the music, which may also generate possible imagery that portrays the dynamic of life in a city. Indeed beyond the words, Weir has successfully utilized sounds to demonstrate this in the composition. Listeners can freely and in an individualized way form a visual experience.

What Weir has done in the composition is one step deeper than merely matters of pitch and rhythm; she evokes images in her music, creates musical meaning and communication. Indeed, like a poet, she often manipulates musical syntax to engender meaning in her instrumental music, linking sound to our daily experiences. Her descriptive works not only provide the listeners with different musical experiences, but also have contributed to the course of 20th-century music. 


\section{References}

BRUCE, David. (2012) Judith Weir Interview. Composition: Today, 19 February 2012. (Accessed: December 7, 2013).

http://www.compositiontoday.com/interviews/judith_weir.asp

COLTON, Lisa. (2010) The Female Exotic: Tradition, Innovation, and Authenticity in the Reception of Music by Judith Weir. Contemporary Music Review, vol. 29, no. 3 (Dec). p.277-289.

GILLIES, Anne Lorne. (2010) Songs of Gaelic Scotland. UK: Birlinn Limited.

HUGHES, Bernard and Judith Weir. (2005) Judith Weir in Conversation. Tempo, vol. 59, no. 234 (Oct). p.20-27.

TILDEN, Imogen. (2014) Judith Weir: the female music master with royal seal of approval. The Guardian, July 3, 2014. (Accessed: April 8, 2015)

http://www.theguardian.com/music/2014/jul/03/judith-weir-master-of-thequeens-music-candidate

TRAVIS, James. (1938) Irish National Music. The Musical Quarterly, vol. 24, no. 4 (Oct). p.451-480.

WEIR, Judith. Distance and Enchantment. Chester Music, CH60854.

Program notes by Judith Weir. (Accessed: April 8, 2015)

http://www.musicsalesclassical.com/composer?category=Works\&workid=2746

Program note to Piano Trio. (Accessed: July 3, 2015)

http://www.musicsalesclassical.com/composer?category=Works\&workid=2746

Note about the author

Kheng Keow Koay is an Associate Professor of Musicology in the School of Music at National Sun Yat-sen University, Taiwan. Her research interests focus on the late 20thand-early 21st centuries. Koay's articles and chapters appear in numerous scholarly journals and books and have been presented at several international conferences. She is the author of Tracing the Beats: The Fusion of American Vernacular and Western Art Music (2012), and The Kaleidoscope of Women's Sounds in Music of the Late 20th and Early 21st Centuries (2015). 